The purpose of moving Plan B to Schedule II was to make it more accessible to women (thus reducing unwanted pregnancies and abortions), while still ensuring the appropriate level of counselling from a trained health professional. Pharmacists have no interest in a woman's sexual history except to determine if Plan B, which has maximum effectiveness for only 72 hours, is appropriate for their situation, as outlined in the assessment in SOGC's clinical practice guidelines on EC. ${ }^{3}$ The guidelines are not new and represent best standards of practice. A physician or nurse practitioner would ask a woman requesting EC the same questions. Many women who ask for Plan B have a lot of questions and misinformation, and appreciate the opportunity to speak with a pharmacist. Pharmacists frequently find that a fair number of women who ask for EC do not, in fact, require it and therefore do not pay for or use an unnecessary drug. When providing EC, pharmacists also routinely refer women to a physician for long-term birth control and screening for STDs. ${ }^{4}$

It is interesting that the article concludes by admitting that no women have complained to privacy commissioners. We believe that women are actually benefiting from pharmacist counselling on EC, and this is an issue manufactured by $C M A J$ to grab some headlines. The real health issue that $C M A J$ should be addressing is that in Canada $I$ in 4 pregnancies ends in abortion. Increased access to emergency contraception with an opportunity for the woman to consult with a health professional can significantly reduce the number of unwanted pregnancies.

\section{George Murray}

President, Canadian Pharmacists Association

\section{REFERENCES}

I. Eggertson L, Sibbald B. Privacy issues raised over Plan B: women asked for names, addresses, sexual history. CMAJ 2005;173(I2):1435-6.

2. Emergency contraception moves behind the counter [editorial]. CMAJ 2005;172(7):845.

3. Society of Obstetricians and Gynaecologists of Canada. SOGC Clinical Practice Guidelines. 2003. Available: www.sogc.org/guidelines/pdf/psızı.pdf (accessed 2005 Dec I2).
4. Soon JA, Levine M, Osmond BL, et al. Effects of making emergency contraception available without a physician's prescription: a population-based study. $C M A J$ 2005;172(7):878-83.

Competing interests: None declared.

DOI:I0.1503/cmaj.051612

\section{[CMAJ responds:]}

We agree that Plan B's nonprescription status is a step in the right direction. ${ }^{1}$ We have no interest in waging a "campaign" against pharmacists, only in examining the potential impact of mandatory counselling on individual women. Our news article on emergency levonorgestrel (Plan $\mathrm{B})^{2}$ presents divergent points of view on behind-thecounter access, including that of the CPhA. Women we spoke to reported varying degrees of comfort with the dispensing process.

If controversy results from reporting on actual policies, so be it. The absence of direct complaints does not settle the matter; one may reasonably speculate that it indicates a general level of comfort with the dispensing procedure, but it may also reflect a lack of awareness of privacy guidelines and complaints procedures, or a reluctance to bring further attention to a transitory personal circumstance. Whatever the case may be, more than one provincial commissioner has thanked the journal for bringing this issue to their attention, and the Ontario College of Pharmacists has already agreed to revise their guidelines. ${ }^{3}$ The question of the security of data in a convenience store or supermarket is moot, as off-the-shelf availability implies that no personal information would be requested in the first place.

\section{Anne Marie Todkill \\ Senior Deputy Editor \\ CMAJ}

\section{REFERENCES}

I. Emergency contraception moves behind the counter [editorial]. CMAJ; 2005;172(7):845.

2. Eggertson L, Sibbald B. Privacy issues raised over Plan B: women asked for names, addresses, sexual history. CMAJ 2005;173(I2):I435-6.

3. Information and Privacy Commissioner/Ontario. Controversial morning-after pill screening form scrapped in Ontario [news release]. 2005 Dec 7.

DOI:IO.I503/cmaj.I050264

\section{Biopeptides and immune exclusion}

Successful probiotics have the ability to adhere to the gut preventing attachment of pathogenic bacteria and help to restore immunologic quiescence. Unfortunately, Nandini Dendukuri and colleagues' systematic review ${ }^{1}$ was unable to find clinical benefit for treatment of Clostridium difficile-associated diarrhea (CDAD).

The important question is, Can probiotics or biologically active peptides induce a lasting immune response? Probiotics stimulate the synthesis and secretion of polymeric IgA, the antibody that protects mucosal surfaces against harmful bacterial invasion, the concept underlying immune exclusion. Appropriate colonization with probiotics can thus help to produce a balanced $\mathrm{T}$ helper (Th) cell response. An imbalance in Th cells partly contributes to clinical disease: Th2 imbalance contributes to atopic disease and Thr imbalance contributes to Crohn's disease and Helicobacter pylori-induced gastritis.

LeBlanc and colleagues ${ }^{2}$ demonstrated that oral administration of an immunologically active peptide (derived after extensive proteolysis by Lactobacillus helveticus) enhanced immunomodulatory action and increased IgA+ Blymphocytes in the intestinal lamina propria of mice, and offered protection against further Escherichia coli $0157: \mathrm{H}_{7}$ challenge. Benyacoub and colleagues ${ }^{3}$ showed that the probiotic organism Enterococcus faecium SF68 offered specific humoral and cellular (increased $\mathrm{CD}_{4}+$ in Peyer's patches and spleen) responses against Giardia intestinalis infection in mice.

Perhaps we are just beginning to understand the complex coexistence and interdependence between microbes and man.

\section{Sujoy Khan}

Department of Immunopathology

St. Bartholomew's Hospital

West Smithfield, London, UK

\section{REFERENCES}

I. Dendukuri N, Costa V, McGregor M, et al. Probiotic therapy for the prevention and treatment of 
Clostridium difficile-associated diarrhea: a systematic review. CMAJ 2005;173(2):167-70.

2. LeBlanc J, Fliss I, Matar C. Induction of a humoral immune response following an Escherichia coli peptidic fraction derived from Lactobacillus helveticus-fermented milk. Clin Diagn Lab Immunol 2004;II(6):II7I-8I.

3. Benyacoub J, Perez PF, Rochat F, et al. Enterococcus faecium SF68 enhances the immune response to $\mathrm{Gi}$ ardia intestinalis in mice. J Nutr 2005;135(5):II7I-6.

DOI:I0.1503/cmaj.I050178

\section{Drug safety in Canada:}

\section{2 steps forward, 1 step back}

Enhancement of patient safety has become a priority for health care practitioners and organizations. Adverse medication events remain a major concern, as drug error is a significant cause of adverse outcomes for hospital inpatients. ${ }^{1}$ Patients are particularly vulnerable to medication error during the perioperative period. The leading cause of malpractice suits for Canadian anesthesiologists is medication error, and misidentification of drugs is the most frequent underlying problem. ${ }^{2,3}$

Improved safety requires a team effort with a focus on patients' wellbeing. ${ }^{4}$ Thus, it is disturbing that AstraZeneca has marketed in Canada a product that fails to meet the minimum labelling standard set out in the Food Or57: $\mathrm{H}_{7}$ infection with an immunomodulatory

Competing interests: None declared.

and Drugs Act.

Bupivacaine is a potent, potentially lethal local anesthetic that is used for local infiltration and for spinal and epidural anesthesia. It is considerably more cardiotoxic than many other local anesthetics. The label on the bupivacaine Polyamp ${ }^{\circledR}$ ampoule sold by AstraZeneca does not include the generic name of the drug, but rather identifies the product only by the brand name, Sensorcaine (Fig. I). ${ }^{5}$

The Food and Drugs Act states that "the inner and outer labels of a drug shall show (i) the proper name, if any, of the drug which, if there is a brand name for the drug, shall immediately precede or follow the brand name in type not less than one-half the size of that of the brand name; (ii) if there is no proper name, the common name of the drug." The act also specifies that "No person shall sell a drug that is not labelled as required by these Regulations."

Clearly, the Sensorcaine packaging does not meet these legal requirements. This situation raises several disturbing questions. Why would an international pharmaceutical firm design ampoule labels with an emphasis on marketing rather than patient safety? How could this product bypass scrutiny by Health Canada and be introduced into Canadian hospitals? Once the

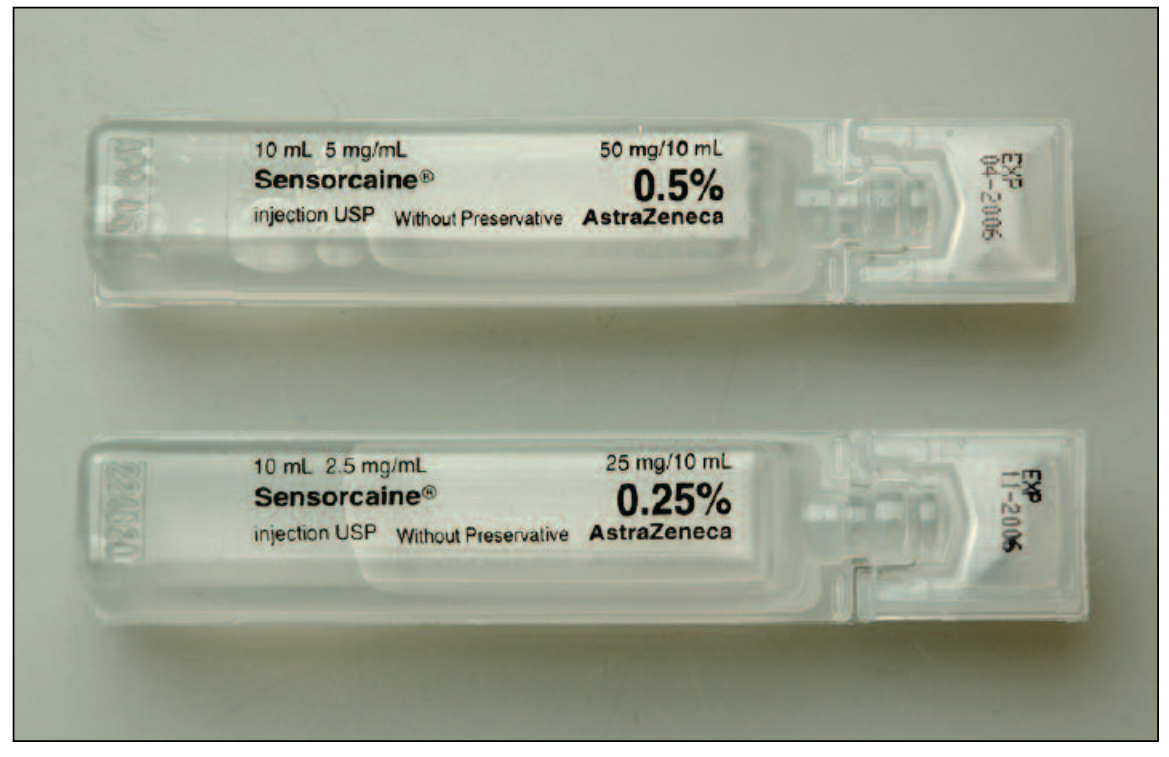

Fig. 1: Polyamp ${ }^{\circledR}$ ampoules containing bupivacaine are labelled with the company's brand name, Sensorcaine, rather than the generic name, bupivacaine. oversight was brought to the attention of AstraZeneca, why did the manufacturer not post warnings and apply additional adhesive labels to the ampoule until a new product, appropriately labelled, was available?

Physicians and health care providers must demand that the pharmaceutical industry "join the team" and make patient safety more important than marketing considerations.

\section{Beverley A. Orser}

Canada Research Chair in

Anesthetic Drugs

Professor of Physiology

and Anesthesia

Chair, Drug Safety Committee

of the Canadian Society of

Anesthesiologists

Claire Dionee

Assistant Professor of Anesthesia

Department of Anesthesia

St. Boniface Hospital

Winnipeg, Man.

Sylvia Hyland

Vice President

Institute for Safe Medication

Practices Canada

Toronto, Ont.

\section{REFERENCES}

I. Baker GR, Norton PG, Flintoft V, et al. The Canadian adverse events study: the incidence of adverse events among hospital patients in Canada. CMAJ 2004;I7O(II):I678-86.

2. Orser BA, Byrick R. Anesthesia-related medication error: time to take action. Can J Anesth 2004;5I: 756-6o.

3. Medication error is anesthetic practice: a survey of 687 practitioners. Can J Anesth 2001;48:139-46.

4. Kohn LT, Corrigan JM, Donaldson MS, editors. To err is human: building a safer health system. Washington: National Academy Press, Institute of Medicine; 2000.

5. Bupivacaine injection: check your supplies. ISMP Can Safe Bull 2005 Jul 21;5(5). Available: www.ismpcanada.org/download/ISMPCSB2005-05Bupivacaine .pdf (accessed 2005 Nov 28).

6. C.or.004 \& C.0I.003 The Food and Drugs Act, Part C, Drugs, Division I, Dec 30, 2002. p. 396. Available: www.hc-sc.gc.ca/fn-an/alt_formats/hpfb-dgpsa/pdf/legislation/e_e-drugs.pdf (accessed 2005 Nov 28).

DOI:I0.I503/cmaj.I050235

\section{[Response from the manufacturer:]}

When the need to manufacture bupivacaine outside of Canada became a reality, our labelling capability was restricted to the manufacturing equipment at the new sourcing site. We 